\title{
Immunoproteomic identification of immunodominant antigens independent of the time of infection in Brucella abortus 2308-challenged cattle
}

\author{
Jin Ju Lee ${ }^{1}$, Hannah Leah Simborio², Alisha Wehdnesday Bernardo Reyes², Dae Geun Kim², Huynh Tan Hop², \\ Wongi Min², Moon Her', Suk Chan Jung ${ }^{1}$, Han Sang Yoo ${ }^{3}$ and Suk Kim²,
}

\begin{abstract}
Brucellosis is a vital zoonotic disease caused by Brucella, which infects a wide range of animals and humans. Accurate diagnosis and reliable vaccination can control brucellosis in domestic animals. This study examined novel immunogenic proteins that can be used to detect Brucella abortus infection or as an effective subcellular vaccine. In an immunoproteomic assay, 55 immunodominant proteins from B. abortus 544 were observed using two dimensional electrophoresis (2DE) and immunoblot profiles with antisera from B. abortus-infected cattle at the early (week 3), middle (week 7), and late (week 10) periods, after excluding protein spots reacting with antisera from Yersinia enterocolitica 0:9-infected and non-infected cattle. Twenty-three selected immunodominant proteins whose spots were observed at all three infection periods were identified using MALDI-MS/MS. Most of these proteins identified by immunoblot and mass spectrometry were determined by their subcellular localization and predicted function. We suggest that the detection of prominent immunogenic proteins during the infection period can support the development of advanced diagnostic methods with high specificity and accuracy; subsidiarily, these proteins can provide supporting data to aid in developing novel vaccine candidates.
\end{abstract}

\section{Introduction}

Brucella spp. are the etiological agents for brucellosis, a debilitating and chronic disease infecting a variety of domestic animals and humans. Brucellosis is characterized by abortion and sterility in livestock as well as undulant fever, arthritis and neurological disorders in humans [1]. Definitive diagnosis is commonly performed by isolation and identification of the causative organism(s), but because the isolation is time-consuming and dangerous, serological analysis is widely preferred [2]. Several specific serological tests have been developed for the definitive diagnosis of brucellosis, and these tests have been upgraded repeatedly to obtain reliable data [3]. However, a large number of tests still rely on presumptive evidence of

\footnotetext{
* Correspondence: kimsuk@gnu.ac.kr

${ }^{2}$ Institute of Animal Medicine, College of Veterinary Medicine, Gyeongsang

National University, Jinju, 660-701, Republic of Korea

${ }^{4}$ Institute of Agriculture and Life Science, Gyeongsang National University,

Jinju, 660-701, Republic of Korea

Full list of author information is available at the end of the article
}

infection. Most serological tests for Brucella infection use antibodies against common antigens of Brucella [4]. O-polysaccharide (OPS), a well-known immunodominant epitope in smooth lipopolysaccharide (SLPS) is a commonly used antigen in serological tests for the diagnosis of brucellosis [5,6]. Consequently, the serological diagnosis of brucellosis is complicated by cross-reactions of the antibodies against other Gram-negative bacteria, such as $Y$. enterocolitica $\mathrm{O}: 9$, which have conserved and highly analogous OPS structures $[7,8]$. Therefore, it is crucial to discover highly specific Brucella antigens that are immunogenic in the host. Several studies have focused on the use of antigenic proteins for alternative diagnostic methods and to improve vaccine efficacy. Recent studies have focused on the use of immunogenic proteins for serodiagnosis of brucellosis [9].

Several immunogenic proteins of $B$. abortus have been identified [10], but the antigens that are immunogenic at different stages of the infection have not been defined. 
Because Brucella causes latent infection, knowledge concerning the different stages of infection is important for the diagnosis and control of the disease. In this study, we obtained antisera against $B$. abortus from experimentally infected cattle at different stages of infection and studied unique immunogenic proteins to validate the immunogenic relationships and potential immunodominant markers at different stages of infection.

\section{Materials and methods}

\section{Bacterial strains and culture conditions}

The standard reference strains B. abortus 2308 and $B$. abortus 544, which are known as virulent biovar 1 strain, and $Y$. enterocoitica O:9 used in the present study were obtained from the Laboratory of Bacteriology Division in the Animal and Plant Quarantine Agency, Korea. The bacteria were cultured at $37{ }^{\circ} \mathrm{C}$ with aeration until the cells entered stationary phase. Subsequently, the number of viable bacteria was evaluated by plating 10 -fold serial dilutions (made using PBS) on Brucella agar plates.

\section{Preparation of antisera}

Twenty-five apparently healthy Korean native heifers (Hanwoo) aged 18-20 months were used in this study. All animals were seronegative for brucellosis before immune challenge, as assessed by the standard tube agglutination test (STAT) and Rose Bengal test (RBT), which are internationally accepted serological tests for bovine brucellosis described by the OIE [5]. The cattle were divided into 3 groups: B. abortus-infected $(n=10), Y$. enterocoitica O:9-infected $(n=10)$ and uninfected controls $(n=5)$. Bacterial inoculation was performed as described in previous methods [11]. Briefly, the first group was inoculated with $4 \times 10^{7} \mathrm{CFU}$ of B. abortus 2308/ head injecting a total of $100 \mu \mathrm{L}(50 \mu \mathrm{L}$ of inoculum per eye) via the intraconjunctival route. The second group was inoculated with $5 \times 10^{6} \mathrm{CFU}$ of $Y$. enterocoitica O:9/ head 3 times by 1 day interval via subcutaneous injection. The 5 cattle in the uninfected control group were inoculated with sterile PBS. After immune challenge, antisera against $B$. abortus were collected at three stages of infection; early (week 3), middle (week 7), and late (week 10). These time points in three stages of infection were determined based on low serological variations among individuals and high titer values. Samples were collected from all cattle in all groups. Using serological tests, 3 samples of each B. abortus-infected antisera (RBT-positive and STAT titers of $>1: 400$ at 3, 7, and 10 weeks post-challenge), $Y$. enterocoitica-infected antisera (RBT-negative and STAT titers of 1:200 against Brucella antigen at 3, 7 and 10 weeks post challenge), and non-infected sera were selected and used for immune analysis. The experimental procedures were approved by the ethical committee as NVRQS-AEC-2008-12, and the infected animals were euthanized according to the protocol of the Institution for Animal Care \& Use Committee in Korea.

\section{Preparations of antigens}

Antigens were prepared as a protein mixture of whole cells including cell envelopes for proteomic analysis using a modification of a previously described procedure [10]. Briefly, B. abortus 544 cultures were centrifuged at $8000 \times g$ for $20 \mathrm{~min}$ at $4{ }^{\circ} \mathrm{C}$ and washed 3 times with icecold PBS (pH 7.6) by centrifugation. The bacterial pellet was resuspended in $50 \mathrm{mM}$ Tris- $\mathrm{HCl}(\mathrm{pH}$ 7.6) containing a complete protease inhibitor cocktail (PIC) and then sonicated on ice using a Sonifier 750 (Branson Ultrasonics, USA). The sonicated solution was centrifuged at $12000 \times g$ for $1 \mathrm{~h}$ at $4{ }^{\circ} \mathrm{C}$, and the pellet was resuspended in lysis buffer (5 M urea, $2 \mathrm{M}$ thiourea, $2 \%$ CHAPS, 1\% SB 3-10, 1\% DTT, and containing PIC) followed by incubation at $22{ }^{\circ} \mathrm{C}$ for $1 \mathrm{~h}$ with vigorous agitation. After centrifugation at $100000 \times g$ for $30 \mathrm{~min}$, the supernatant was collected. The protein concentration was quantified using the Bradford assay [12].

\section{Isoelectric focusing (IEF) and 2D SDS-PAGE}

IEF and 2DE were conducted using a previously described method [13] with modifications. Eighteen-centimeter IPG strips (pH 3-10 and 4-7, GE Healthcare, USA) were rehydrated for $14 \mathrm{~h}$ at $22{ }^{\circ} \mathrm{C}$ with the lysed proteins and rehydration buffer (7 M urea, $2 \mathrm{M}$ thiourea, 2\% CHAPS, $0.2 \%$ DTT, 0.5\% IPG buffer (pH 4-7), and 0.002\% bromophenol blue). IEF was performed on a Protean IEF gel (GE Healthcare) at $20{ }^{\circ} \mathrm{C}$ for $14 \mathrm{~h}$ using the following conditions: $500 \mathrm{~V}$ for $1 \mathrm{~h}$, gradient phase of $1000 \mathrm{~V}$ for $1 \mathrm{~h}$, $1000 \mathrm{~V}$ for $3 \mathrm{~h}$, gradient phase of $10000 \mathrm{~V}$ for $3 \mathrm{~h}$, $10000 \mathrm{~V}$ for $5 \mathrm{~h}, 50 \mathrm{~V}$ for $30 \mathrm{~min}$ and a final phase of $50 \mathrm{~V}$ for $30 \mathrm{~min}$. After IEF, each strip was equilibrated in $5 \mathrm{~mL}$ of equilibration buffer I ( $6 \mathrm{M}$ urea, $50 \mathrm{mM}$ Tris- $\mathrm{HCl}$ $\mathrm{pH} 8.8,1 \%$ DTT, $30 \%$ glycerol, $2 \%$ SDS, and $0.002 \%$ bromophenol blue) for $15 \mathrm{~min}$ at $22{ }^{\circ} \mathrm{C}$ and then in equilibration buffer II (6 M urea, $50 \mathrm{mM}$ Tris- $\mathrm{HCl} \mathrm{pH} 8.8,2.5 \%$ iodoacetamide, $30 \%$ glycerol, $2 \%$ SDS, and $0.002 \%$ bromophenol blue) under the same conditions. The equilibrated strips were loaded on the top of $12 \%$ SDS-polyacrylamide gels and sealed with melted 1\% agarose solution. The proteins were two-dimensionally separated in resolving buffer (25 mM Tris pH 8.8, 192 mM glycine, 0.1\% SDS) using Criterion electrophoresis equipment (Bio-Rad) equipped with a cooling device (Lauda E100, Germany), kept at $25^{\circ} \mathrm{C}$ and supplied with regular power in two steps: $5 \mathrm{~W} /$ gel for $30 \mathrm{~min}$ and $20 \mathrm{~W} / \mathrm{gel}$ until the protein dye reached the bottom of the gel (approximately $5 \mathrm{~h}$ ). The separated proteins were transferred to PVDF membranes (Millipore, USA) for immunoblotting analysis; simultaneously, replicate gels containing the same protein samples were 
silver-stained to visualize the proteins. Three replicates of 2DE were performed in independent experiments.

\section{Immunoblotting with antisera}

The proteins were completely transferred to membranes using the TE70/77 PWR Semi-Dry Transfer Unit (GE Healthcare) according to the manufacturer's instructions. The membranes were blocked for $1 \mathrm{~h}$ at room temperature using $5 \%$ rabbit serum in Tris-buffered saline containing $0.1 \%$ Tween-20 (TBS-T) and then washed three times for $20 \mathrm{~min}$ in TBS-T. The blots were incubated overnight at $4{ }^{\circ} \mathrm{C}$ with a $1: 500$ dilution of the antisera derived from the immune-challenged and control cattle. The blots were then incubated for $1 \mathrm{~h}$ at room temperature with a 1:5000 dilution of goat anti-bovine IgG HRP-conjugated antibody (Sigma, USA). After washing, the immunolabeling was detected using ECL Western blotting reagents (GE Healthcare). Finally, specific immunogenic proteins were visualized using a ChemiDoc XRS Camera and the Quantity One 1D analysis software (Bio-Rad).

\section{Gel image analysis and in-gel trypsin digestion}

The silver-stained 2D gels were scanned using an ImageScanner $^{\text {ma }}$ (GE Healthcare) and cropped using ImageQuant TL (GE Healthcare). Automatic gel-image alignment and spot detection along with spot matching were performed using Progenesis SameSpots v 2.0 (Nonlinear Dynamics) to allow for more accurate spot identification [14]. Each gel was run in triplicate in parallel with three independent sample preparations. The spot matching across all gels without omitting values was set as a requirement for spot merging for data analysis. An average gel with best resolution was generated using the three independent replicates by including only those protein spots that were present in at least two of the replicates. The common spots, in keeping with shape and intensity over all replicates, were selected for normalization of spot volumes to equalize the probable variation in staining trait. The gel containing all spots on final average gel was used and transferred to the PVDF membrane which subsequently was subjected to react with antisera from cattle. In addition, image alignment and spot matching analyses were performed on the gel spots and the immunogenic protein spots detected by immunoblotting. The selected spots were manually excised from the gels, and the gel plugs containing the proteins were enzymatically digested with porcine trypsin (modified sequencing grade; Promega, USA) as described previously [13]. The spots were incubated with $50 \mathrm{mM}$ ammonium bicarbonate $\left(\mathrm{NH}_{4} \mathrm{CO}_{3}\right.$, $\mathrm{pH} 7.8) / 50 \%$ acetonitrile (ACN) for $1 \mathrm{~h}$ at $22{ }^{\circ} \mathrm{C}$ to destain them and were washed and then dehydrated in $\mathrm{ACN}$. The dehydrated spots were vacuum-dried to remove the solvent and then rehydrated overnight at $37{ }^{\circ} \mathrm{C}$ by digestion with trypsin $(10 \mathrm{ng} / \mu \mathrm{L})$ in $50 \mathrm{mM} \mathrm{NH}_{4} \mathrm{CO}_{3}$ (pH 7.8). The tryptic peptides were extracted with $0.1 \%$ trifluoroacetic acid (TFA)/50\% can, and the combined extracts were vacuum-dried by centrifugation and resuspended in $0.5 \%$ TFA. The peptide mixture was desalted using ZipTip plates (Millipore) and then eluted with $0.2 \%$ TFA $/ 50 \%$ ACN. Finally, the resulting solution was mixed with the matrix $(10 \mathrm{mg} / \mathrm{mL} \alpha$-cyano-4-hydroxycinnamic acid in $50 \% \mathrm{ACN} / 1 \% \mathrm{TFA})$.

\section{Protein identification by MALDI-TOF MS /MS analysis}

All spectra were collected using an ABI 4700 proteomics analyzer Plus TOF-TOF Mass Spectrometer (Applied Biosystems, USA). MS/MS data were obtained using this instrument with a Nd:YAG laser with a $200 \mathrm{~Hz}$ repetition rate, and accumulation of up to 4000 shots were performed for each spectrum from which the three highest intense peaks were processed to an enhanced resolution. When the three intense peaks were subjected to downstream analysis, these were ignored for a period of $60 \mathrm{~s}$. MS/MS mode was operated with $2 \mathrm{keV}$ collision energy supplying air as the collision gas, which resulted in completion of nominally single collision conditions. MS/MS data were obtained using the default instrument calibration without internal or external calibration. The quality control parameters included based on the Mascot algorithm were the following: maximum of one missed cleavage permitted by trypsin, fixed modification (including residue specificity) of carbamidomethyl, variable modifications (including residue specificity) of oxidation, charge state of 12 to 14, mass tolerance for peptide ion $(\mathrm{m} / \mathrm{z})$ of 0.1 to $0.2 \mathrm{Da}$, cut-off score/expectation value for accepting individual MS spectra of highest expectation (probability on profound search, PPS). All protein identifications were made by only single protein spot and were collected using a score with the minimal number of high quality peptides per protein is 22 . Peptide mass data were used to query the NCBI protein sequence and annotated genome databases of Brucella using the Mascot search engine (Matrix Science, London, UK) [15]. Based on the sequences identified using mass spectrometry, biological information on the chosen proteins was retrieved using the EXPASY database [16]. The sub-cellular localizations of bacterial proteins were predicted using PSORTb v. 2.0.4 [17]. Functional annotations were made based on the cluster of orthologous groups (COG) protein database generated by comparing all of the complete sequences of microbial genomes from the NCBI COG [18].

\section{Results}

2DE profiles of whole-cell antigens from B. abortus 544

The annotated 2DE proteome map of whole-cell proteins from B. abortus 544 is shown in Figure 1A. A total of 1181 protein spots were detected on the silver-stained 


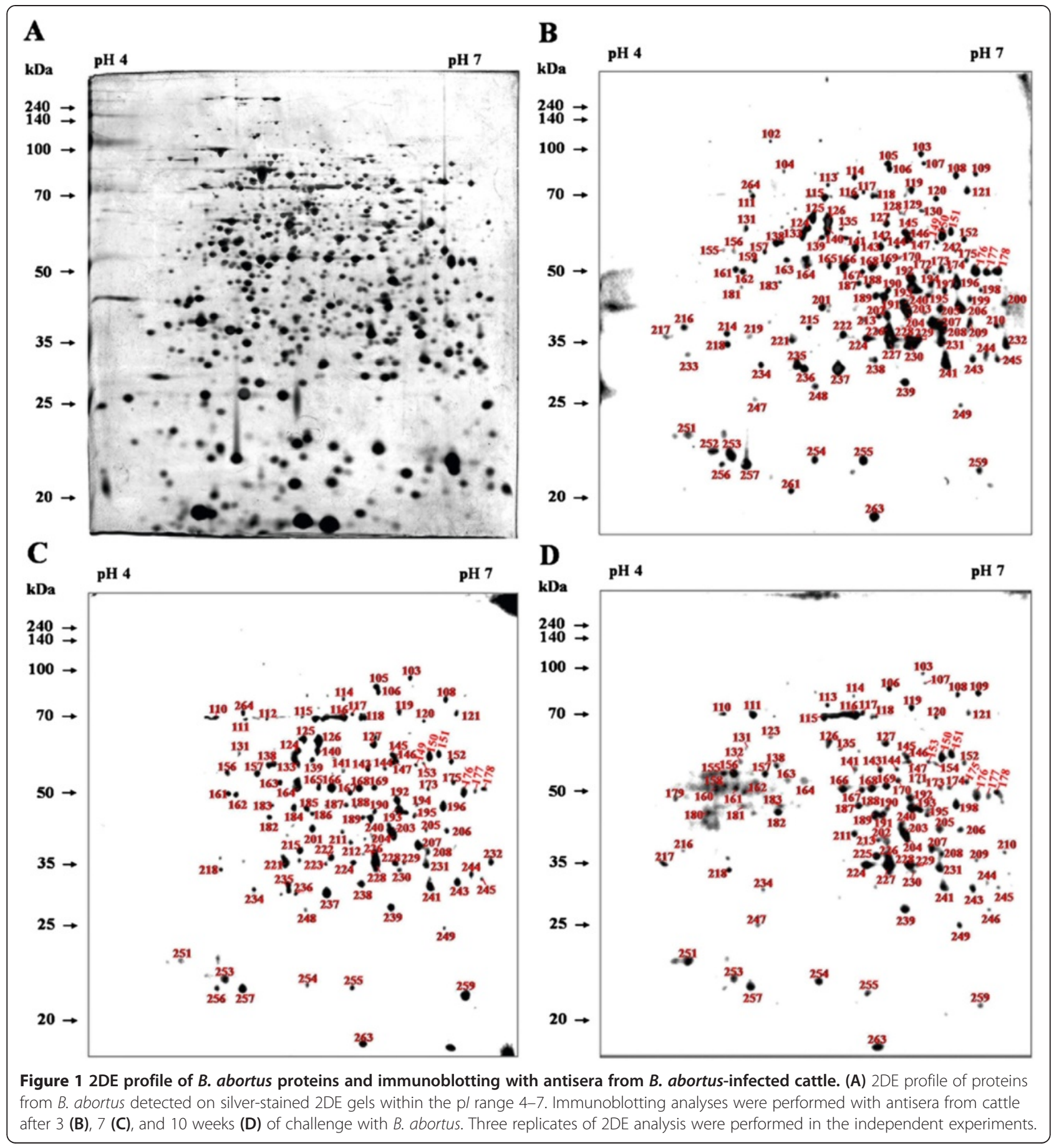

2DE gels within the $\mathrm{p} I$ and molecular weight $\left(M_{r}\right)$ ranges of 4-7 and 20-240 kDa, respectively. The 2DE map profiles of the best resolution were obtained from most of the detected spots in the 2DE gels of the three replicates from separate experiments. These replicates were selected based on equal $2 \mathrm{D}$ patterns and spot numbers reactive to individual serum from three different infection periods. The mean $\mathrm{p} I$ and $M_{\mathrm{r}}$ of all protein spots detected were 5.62 and $40.52 \mathrm{kDa}$, respectively. Using the broad $\mathrm{pH}$ range from $3-10$, the protein spots with $\mathrm{p} I<4$ or $\mathrm{p} I>8$ were detected at relatively low resolution with few protein spots.

Immunogenic proteins in $B$. abortus at different infection periods and comparison with cross-reacting bacteria By immunoblotting the diverse $B$. abortus proteins detected on 2DE gels, 134, 110, and 106 proteins were recognized using positive antisera from $B$. abortus-infected 
cattle at 3,7 , and 10 weeks of infection, respectively (Figures 1B-D). The negative sera from the non-infected cattle and the positive antisera from the cattle infected with $Y$. enterocolitica O:9 were also used for immunoblotting to exclude non-specific or cross reactions. Few reactions (25 protein spots) were observed using the negative control (NC) and Y. enterocolitica O:9-positive (YP) antisera (Table 1 and Figure 2). The spots reacting to the $B$. abortus-positive (BP) antisera that overlapped with those reacting to the NC (13 spots) and YP (13 spots) antisera were excluded (Figure 3). Among the immunogenic proteins that were not from non-specific and cross-reacting spots, 120 immunodominant proteins (Table 1) were observed using the antisera collected during at least one of the three infection periods, whereas 101,84 , and 78 proteins were specifically observed using BP antisera collected at weeks 3, 7, and 10, respectively (Table 2 and Figure 4). Fifty-five common antigens were predominantly specific to the BP antisera at all three stages of infection (Figure 5A). The percent similarity, calculated as the number of proteins that reacted to the antisera, was $45.83 \%$, suggesting that highly immunogenic proteins were present in the bovine serum within 10 weeks of infection (Table 1). In addition, 19, 10, and 4 common immunoreactive spots were observed at 3 and 7 (Figure 5B), 3 and 10 (Figure 5C), and 7 and 10 weeks (Figure 5D), respectively. Furthermore, 17,6 , and 9 non-matched immunoreactive protein spots were observed, and the percent independence of these immunoreactions were $16.84 \%, 7.14 \%$, and $11.54 \%$ at 3,7 , and 10 weeks, respectively (Table 2).

\section{Identification of immunogenic proteins at different infection stages}

Amongst the 55 immunogenic proteins detected at all three stages of infection, the signal intensities of 23 immunogens were higher than the average when normalized to the total valid spot intensity; these 23 proteins were analyzed using MALDI- MS/MS. The data revealed that several novel immunogenic proteins with diverse ORF had varying values for $M_{\mathrm{r}}$ and $\mathrm{p} I$ in MALDI-MS/MS (Table 3). NCBI BLAST searches of the proteins identified using MALDI-MS/MS show that 10 (43.5\%), 2 (8.7\%) and $2(8.7 \%)$ proteins were predicted to have cytoplasmic, outer membrane-bound periplasmic and ribosomal localization, respectively. However, 9 spots (39.1\%) were unknown proteins. Analysis of each identified protein indicates that 13 of the 23 proteins participate in multiple enzymatic activities. Notably, three hypothetical proteins (spots 187, 218 and 257) encoded by different ORF had putative molecular functions such as catalytic and protein disulfide oxidoreductase activities. The experimental $\mathrm{p} I$ and $M_{\mathrm{r}}$ values from MALDI-MS/MS identification were consistent with the theoretical values for most identified proteins, with the exception of spot 146, which was identified as an $\mathrm{ABC}$ transporter substrate-binding protein; the experimental and theoretical $M_{\mathrm{r}}$ values for this spot had the highest deviations (6.4).

Multiple proteins that were immunoreactive at all stages of infection had varying $\mathrm{p} I, M_{\mathrm{r}}$ and functions. The identified proteins were sorted into functional groups based on the classification of proteins encoded in complete genomes established by COG: 14 were related to transport and metabolism [4 for amino acids (spots 146, 178, 204, and 207), 3 to carbohydrates (spots 118, 164, and 231), 2 to inorganic ions (spots 239 and 240), 2 to nucleotides (spots 151 and 254), 2 to coenzymes (spots 161 and 169), and 1 to secondary metabolites (spot 218)]; 3 were involved in ribosomal structure and biogenesis related to protein translation (spots 162, 203, and 231), and 2 were associated with cellular processes and signaling, including post-translational modification, protein turnover, and chaperones (spots 228 and 253).

Table 1 Comparison of immunoreactive proteins of $B$. abortus after immune challenge in cattle

\begin{tabular}{|c|c|c|c|c|c|c|c|}
\hline \multicolumn{5}{|c|}{ Antisera immunoreactions compared } & \multirow[t]{3}{*}{ No. of matched protein spots } & \multirow[t]{3}{*}{ Total no. of protein spots } & \multirow[t]{3}{*}{ Similarity (\%) } \\
\hline \multicolumn{3}{|l|}{$\mathrm{BP}$} & \multirow[t]{2}{*}{ NC } & \multirow[t]{2}{*}{ YP } & & & \\
\hline Week 3 & Week 7 & Week 10 & & & & & \\
\hline$+^{\mathrm{b}}$ & + & + & + & + & 8 & 162 & 4.94 \\
\hline+ & + & + & + & - & 5 & 137 & 3.65 \\
\hline+ & + & + & - & + & 5 & 137 & 3.65 \\
\hline+ & + & + & - & - & 55 & 120 & 45.83 \\
\hline+ & + & - & - & - & 19 & 42 & 45.24 \\
\hline+ & - & + & - & - & 10 & 36 & 27.78 \\
\hline -c $^{c}$ & + & + & - & - & 4 & 19 & 21.05 \\
\hline
\end{tabular}

NC - negative control, YP - Y. enterocolitica-positive sera, BP - B. abortus-positive sera.

${ }^{a}$ The percent similarity was calculated as the number of proteins common to the compared antisera immunoreactions divided by the total number of proteins in these antisera immunoreactions $\times 100$.

${ }^{\mathrm{b}}$ Positive reaction detected in immunoblotting.

${ }^{\mathrm{c}}$ Negative reaction detected in immunoblotting. 


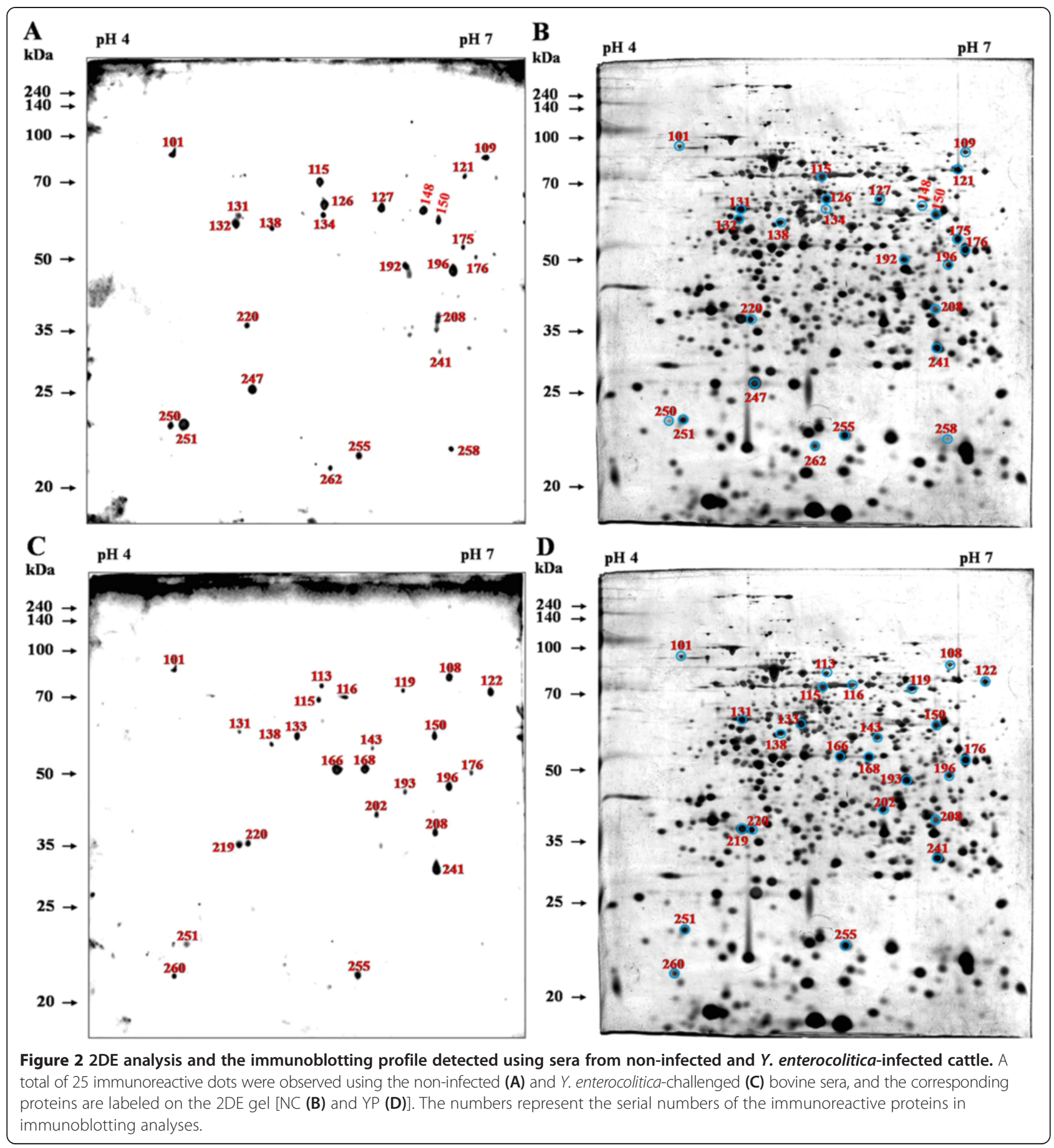

\section{Discussion}

Brucellosis is a re-emerging zoonosis that has regained scientific attention because its pathogenesis in human and animal disease has significantly evolved $[1,19]$. However, the overall burden of this disease remains underestimated and is not well studied. The disease ecology has evolved rapidly in recent years, and there are novel populations with high risk of exposure and the potential to develop chronic or latent infection [20]. Eradication of brucellosis in animals is important for prevention of this disease in human beings and requires optimal diagnosis and vaccination [3]. There are relatively efficient diagnostic tests for brucellosis, and vaccines have been consistently developed; however, there are still several limitations [21,22]. Furthermore, cross-reacting bacteria decrease the specificity of the tests, and this has impeded the control of brucellosis [7]. To address these problems, it is important to develop new strategies for 


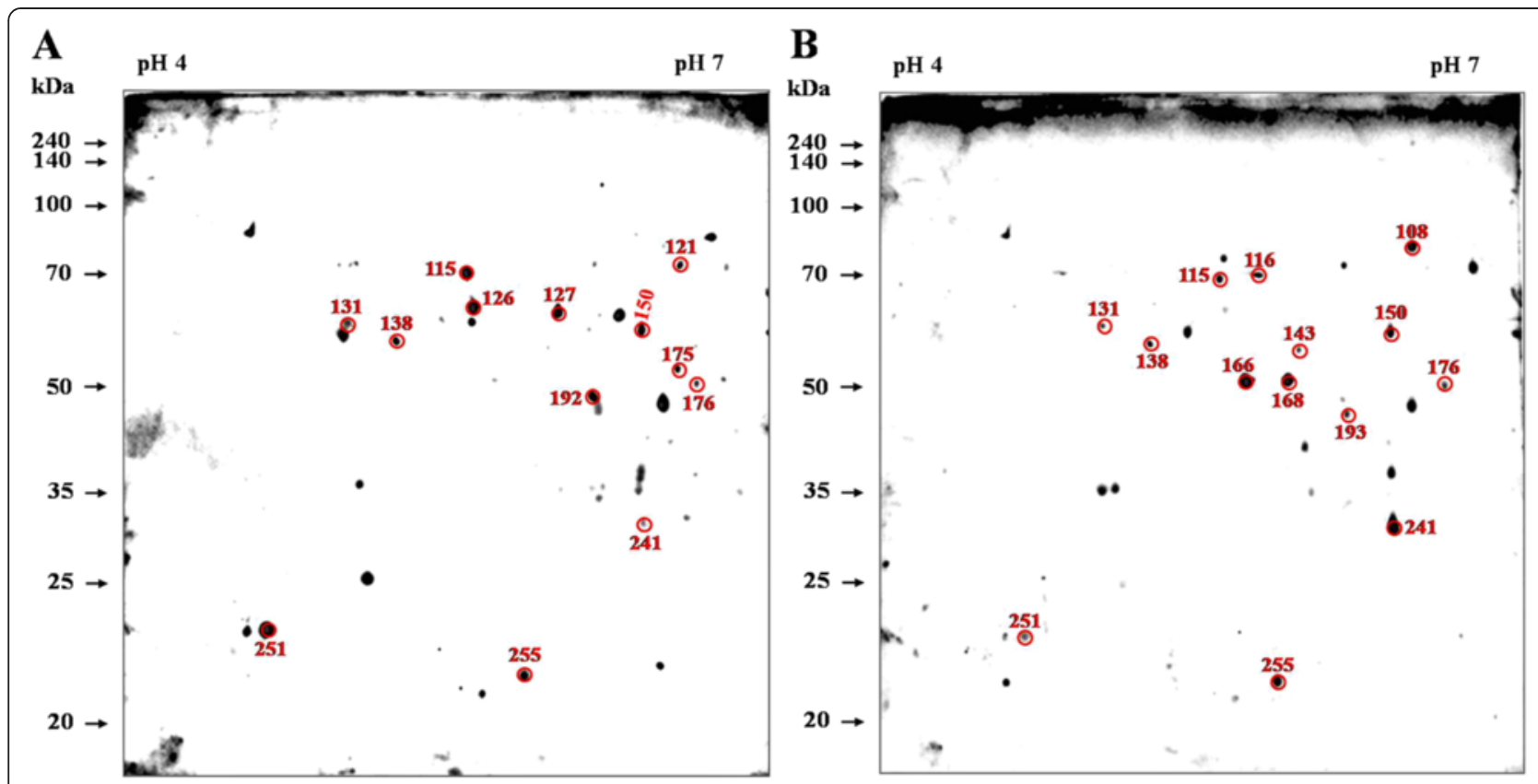

Figure 3 Comparative 2DE analysis of $B$. abortus proteins and immunoblotting profile of non-specific reactions. A total of 13 immunoreactive spots of common antigens that responded to the negative sera from non-infected cattle (A) and positive sera of $Y$. enterocolitica (B), and three types of sera from cattle after 3,7 and 10 weeks of challenge with $B$. abortus were selected. The numbers represent the serial numbers of the immunoreactive proteins in immunoblot analyses.

effective diagnosis with improved specificity. This study focused on identifying immunogenic proteins of Brucella from three different stages of infection (short-, middle-, and long-term) for the improvement of immunodiagnostics. Although distinct sets of Brucella antigens were only a limited set of proteins present at all three time points, these novel immunodominant proteins identified in our study might be suitable for the detection of B. abortus infection.

The 2DE gels containing B. abortus whole cell proteins were subjected to immunoblotting analysis using bovine antisera; the antisera were collected at three different phases of infection: the early (week 3), middle (week 7), and late (week 10) periods after challenge with B. abortus. An important diagnostic problem is the similarity of the O-antigenic side chains of Brucella and other Gramnegative bacteria such as $Y$. enterocolitica O:9 [7]. In this study, 25 protein spots reactive to $Y$. enterocolitica
O:9-positive (YP) antisera and negative control (NC) sera in cattle were detected. By immunoblotting-linked gel image analysis of $B$. abortus proteins, the overlapping spots that were reactive to the $\mathrm{YP}$ and $\mathrm{NC}$ sera were excluded, and the spots that were reactive to the $B$. abortus-positive (BP) antisera at all stages of infection were selected; this analysis identified 120 distinct spots. The total number of spots reactive to the BP antisera at 3,7 , and 10 weeks post-challenge was comparable to the number of common spots (55) observed at all stages of infection. Furthermore, the common spots were $45.83 \%$ similar to those observed by immunoblotting using antisera from all three stages of infection; this suggests that the common immunoreactive spots might represent the proteins that are immunodominant at all stages of infection. The infection time-independent immunodominant proteins of B. abortus comprise proteins expressed from diverse genes encoding transport, metabolic functions and other

Table 2 Comparison of immunoreactive proteins of $B$. abortus that reacted independently with BP

\begin{tabular}{lllll}
\hline & $\begin{array}{l}\text { Antisera (BP) immunoreactions } \\
\text { compared }\end{array}$ & $\begin{array}{l}\text { No. of non-matched } \\
\text { protein spots }\end{array}$ & $\begin{array}{l}\text { Total no. of } \\
\text { protein spots }\end{array}$ & \multicolumn{1}{l}{$\begin{array}{l}\text { Independence (\%) } \\
\text { Periods of challenge }\end{array}$} \\
& week 3 & 17 & 101 & 16.84 \\
& week 7 & 6 & 84 & 7.14 \\
& week 10 & 9 & 78 & 11.54
\end{tabular}

BP - B. abortus-positive sera.

${ }^{a}$ The percent independence was calculated as the number of non-matched proteins to the antisera immunoreactions compared with others divided by the total number of proteins in these antisera immunoreactions $\times 100$. 


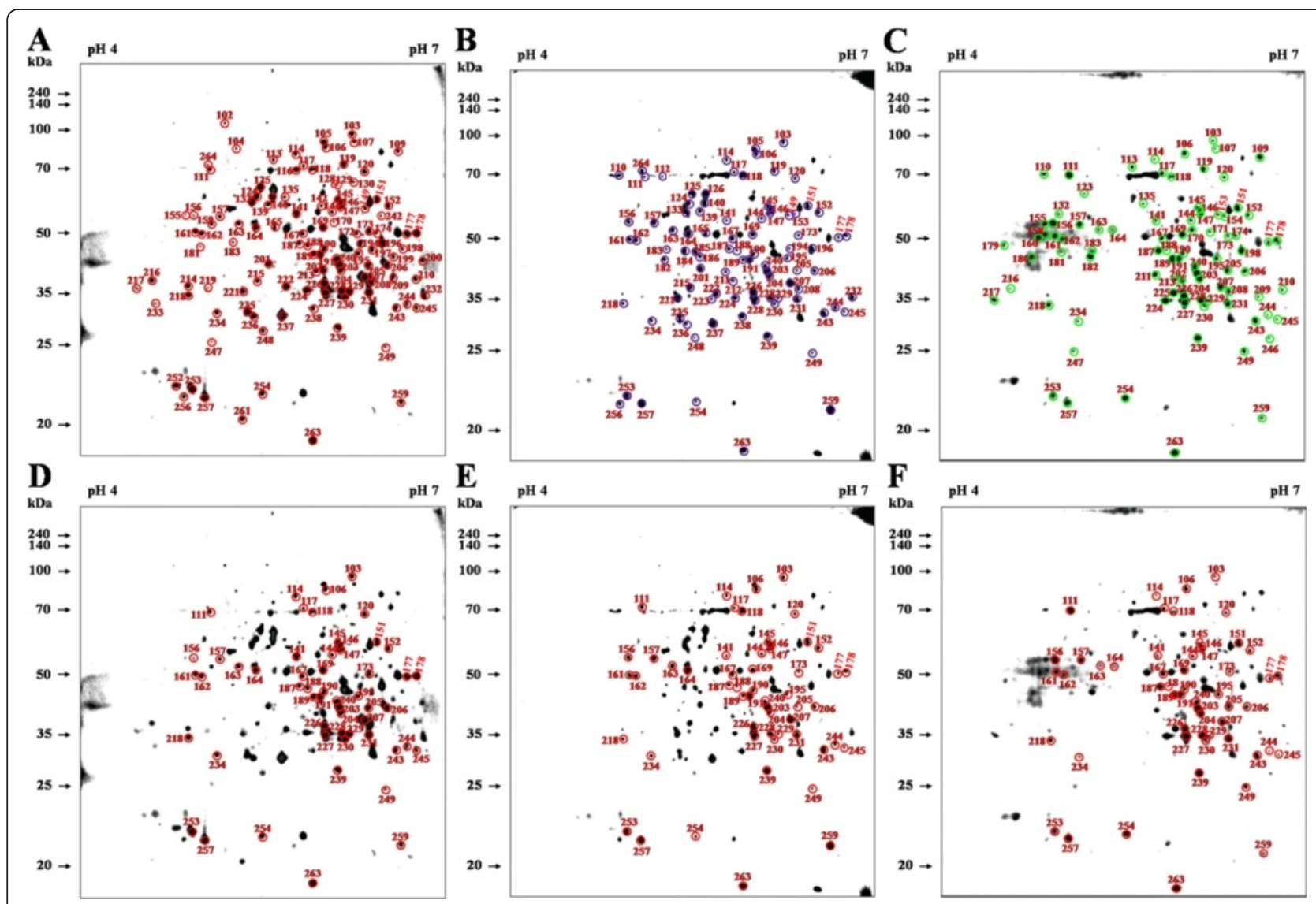

Figure 4 Immunoblotting profile of $B$. abortus proteins responded with $B$. abortus-infected bovine antisera excluding non-specific proteins. Immunoblotting analyses were performed with antisera from cattle after 3,7 , and 10 weeks of challenge with $B$. abortus. After excluding non-specific reactions, a total of 101 (A), 84 (B), and 78 (C) immunoreactive dots, as well as 55 protein spots that reacted with antisera at all 3 stages (D, E, and F), were selected and labeled. The numbers represent the serial numbers of the immunoreactive proteins in immunoblot analyses.

immunogenic proteins. Previous studies have examined the immunogenicity of Brucella antigens but did not correlate this immunogenicity with the stage of infection. Therefore, this study identified several novel immunoreactive proteins in the bovine host based on the stage of infection.

Using the COG approach, most of the identified proteins were assigned functions related to the transport and metabolism of amino acids (60.9\%). The $27.6 \mathrm{kDa}$ DHDPR protein encoded by the $d a p B$ gene had the highest score value; DHDPR was proposed to function in the biosynthesis of lysine and diaminopimelate, but few proteomic studies have examined the role of this protein in Brucella infection [23]. The dapB in Burkholderia pseudomallei is an essential gene that was successfully mutagenized and identified as a beneficial marker [24]. Therefore, because the $B$. abortus $d a p B$-encoded protein elicits an immunodominant response, this protein is a relevant candidate marker for infection. The predicted proteins involved in carbohydrate transport and metabolism included malate dehydrogenase (mdh), which functions in malate metabolism and the tricarboxylic acid cycle. mdh is expressed in response to acidic stress [25] and was broadly identified in B. abortus [10] and B. melitensis [26] using proteomic analyses. The second most frequent group included proteins related to ribosomal structure and protein translation. This group includes two ribosomal proteins, the $30 \mathrm{~S}$ ribosomal protein S2 (RPS2) and the 50S ribosomal protein L25 (RPL25), and one translation elongation factor, EF-Ts (tsf). The RPS2 protein is highly conserved in prokaryotic-type ribosomes and is essential for binding of the ribosomal protein $\mathrm{S} 1$ to the $30 \mathrm{~S}$ ribosomal subunit in E. coli [27]. In Brucella, RPS2 is repressed in response to oxidative stress [25] and is generally identified as the SSU ribosomal protein S1P of B. melitensis and B. abortus $[10,26]$. Additionally, elongation factor Ts (tsf), which is associated with protein translation, might be critical for the immunogenicity of $B$. abortus; this observation is consistent with previous data obtained by global protein analysis in B. melitensis [26]. Our study is the first to report that this protein is immunogenic at all stages of infection. 


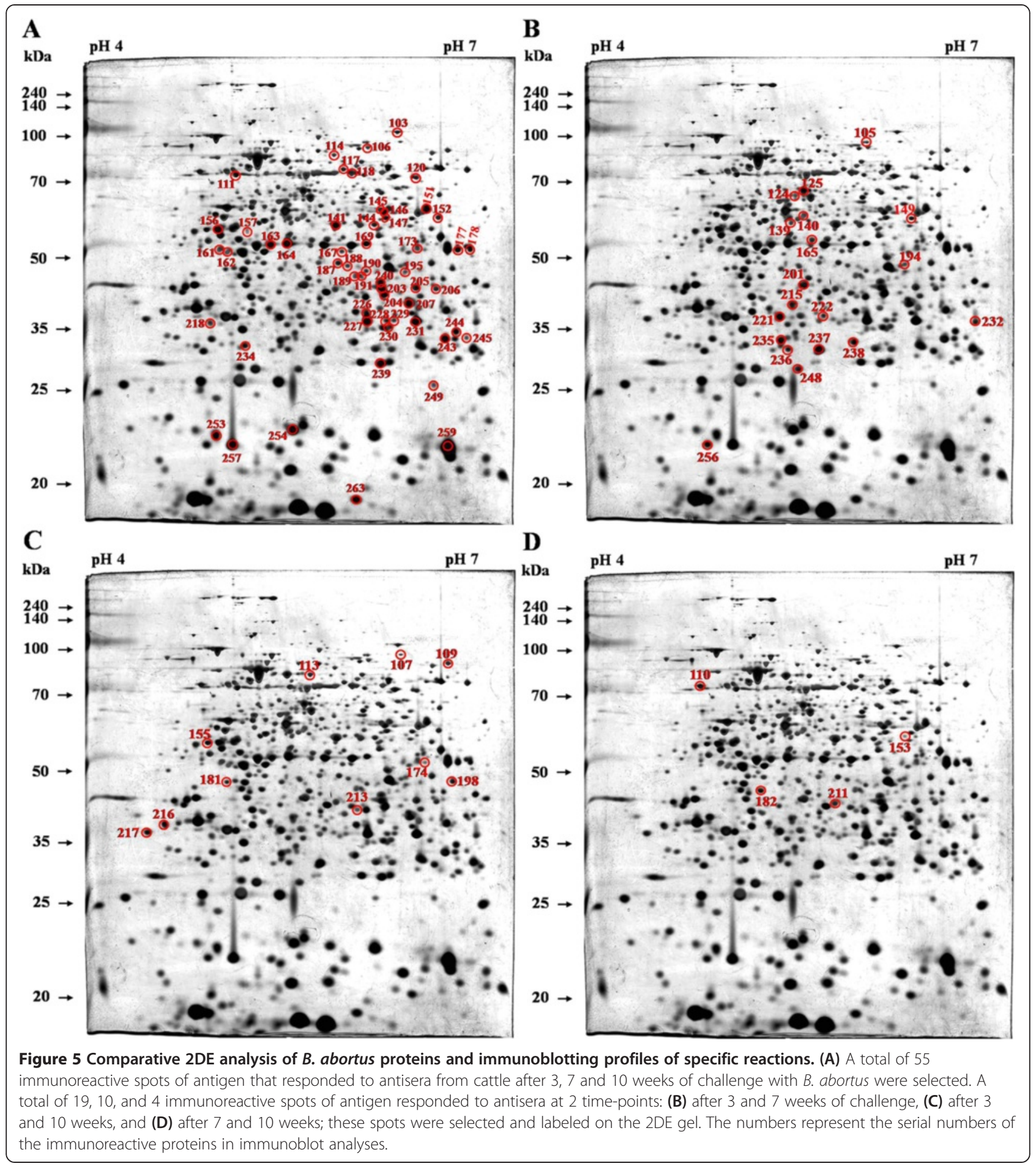

In the group of proteins involved in inorganic ion transport and metabolism, the $22.5 \mathrm{kDa}$ Fe-Mn superoxide dismutase (Fe-Mn-SOD) detected at the $\mathrm{p} I$ of 5.58 is an oxidoreductase with superoxide dismutase activity. The Fe-Mn-SOD protein of B. melitensis is correlated with regulation of the stress response and was identified as a heat-shock protein (Hsp) [25]. Furthermore, the role of metal ions such as $\mathrm{Fe}$ and $\mathrm{Mn}$ in the response to relatively stringent environments has been elucidated with respect to Brucella pathogenesis [28]. Similar to the regulation of $\mathrm{Fe}$ - and/or $\mathrm{Mn}$-SOD in response to heat shock and oxidative stress in some bacteria [29], $B$. abortus Fe-Mn-SOD is an essential factor that regulates specific stress responses inside hosts. Several molecular 
Table 3 Identification of matched immunoreactive proteins of B. abortus that reacted with $B$. abortus-positive bovine antisera

\begin{tabular}{|c|c|c|c|c|c|c|c|c|c|c|c|c|c|c|}
\hline \multirow{2}{*}{$\begin{array}{l}\text { Spot } \\
\text { no. }\end{array}$} & \multirow{2}{*}{ Gene name } & \multirow{2}{*}{$\begin{array}{l}\text { Gene } \\
\text { ID }^{\mathrm{a}}\end{array}$} & \multirow[t]{2}{*}{ Protein identification } & \multirow[t]{2}{*}{ Protein ID ${ }^{a}$} & \multirow{2}{*}{$\begin{array}{l}\text { Accession } \\
\text { no }^{\mathrm{a}}\end{array}$} & \multirow{2}{*}{$\begin{array}{l}\text { Sequence } \\
\text { length }\end{array}$} & \multirow{2}{*}{ Locus tag } & \multirow[t]{2}{*}{ Score } & \multicolumn{2}{|l|}{$M_{r}$} & \multirow[t]{2}{*}{$\mathrm{pl}$} & \multirow{2}{*}{$\begin{array}{l}\text { Sequence } \\
\text { coverage } \\
\text { (\%) }\end{array}$} & \multirow{2}{*}{$\begin{array}{l}\text { Subcellular } \\
\text { locationc }^{c}\end{array}$} & \multirow{2}{*}{$\begin{array}{l}\text { COG functional } \\
\text { category }^{\mathrm{d}}\end{array}$} \\
\hline & & & & & & & & & Experimental & Theorectical $^{b}$ & & & & \\
\hline 118 & BruAb2_0325 & 3341905 & $\begin{array}{l}\text { aldehyde } \\
\text { dehydrogenase }\end{array}$ & YP_223118.1 & Q579C7 & 500 & BruAb2_0325 & 249 & 53744 & 53435 & 5.64 & 29 & unknown & $\begin{array}{l}\text { G: Carbohydrate } \\
\text { transport and } \\
\text { metabolism }\end{array}$ \\
\hline 146 & BruAb2_0024 & 3341776 & $\begin{array}{l}\text { branched chain } \\
\text { amino-acid } A B C \\
\text { transporter substrate- } \\
\text { binding protein }\end{array}$ & YP_222837.1 & Q57A58 & 471 & BruAb2_0024 & 438 & 50740 & 44322 & 6.43 & 25 & $\begin{array}{l}\text { periplasmic } \\
\text { space }\end{array}$ & $\begin{array}{l}\text { E: Amino acid } \\
\text { transport and } \\
\text { metabolism }\end{array}$ \\
\hline 151 & aspC & 3339882 & $\begin{array}{l}\text { aspartate } \\
\text { aminotransferase }\end{array}$ & YP_222177.1 & Q57C18 & 400 & BruAb1_1488 & 193 & 43812 & 43554 & 5.94 & 18 & unknown & $\begin{array}{l}\text { F: Nucleotide } \\
\text { transport and } \\
\text { metabolism }\end{array}$ \\
\hline 161 & BruAb1_0775 & 3339474 & $\begin{array}{l}\text { 3-hydroxyisobutyryl- } \\
\text { CoA hydrolase }\end{array}$ & YP_221504.1 & Q57DZ1 & 349 & BruAb1_0775 & 258 & 38120 & 37802 & 4.84 & 27 & unknown & $\begin{array}{l}\mathrm{H} \text { : Coenzyme } \\
\text { transport and } \\
\text { metabolism }\end{array}$ \\
\hline 162 & tsf & 3340671 & elongation factor Ts & YP_221867.1 & Q57CX8 & 305 & BruAb1_1167 & 367 & 32061 & 31491 & 5.03 & 35 & cytoplasm & $\begin{array}{l}\text { J: Translation, } \\
\text { ribosomal } \\
\text { structure and } \\
\text { biogenesis }\end{array}$ \\
\hline 164 & mdh & 3340925 & malate dehydrogenase & YP_222574.1 & Q57AX1 & 320 & BruAb1_1903 & 76 & 33854 & 33704 & 5.24 & 7 & cytoplasm & $\begin{array}{l}\text { G: Carbohydrate } \\
\text { transport and } \\
\text { metabolism }\end{array}$ \\
\hline 169 & tbpA & 3340057 & $\begin{array}{l}\text { thiamine transporter } \\
\text { substrate binding } \\
\text { subunit }\end{array}$ & YP_222421.1 & Q57BC4 & 334 & BruAb1_1742 & 310 & 36843 & 36752 & 6.06 & 19 & $\begin{array}{l}\text { periplasmic } \\
\text { space }\end{array}$ & $\begin{array}{l}\mathrm{H} \text { : Coenzyme } \\
\text { transport and } \\
\text { metabolism }\end{array}$ \\
\hline 178 & BruAb1_1058 & 3341091 & cysteine synthase A & YP_221767.1 & Q57D78 & 342 & BruAb1_1058 & 417 & 34445 & 36701 & 5.94 & 30 & cytoplasm & $\begin{array}{l}\text { E: Amino acid } \\
\text { transport and } \\
\text { metabolism }\end{array}$ \\
\hline 187 & BruAb2_0291 & 3341871 & $\begin{array}{l}\text { hypothetical protein } \\
\text { BruAb2_0291 }\end{array}$ & YP_223086.1 & Q579F9 & 330 & BruAb2_0291 & 267 & 35457 & 35251 & 5.50 & 26 & unknown & $\begin{array}{l}\text { R: General } \\
\text { function } \\
\text { prediction only }\end{array}$ \\
\hline 203 & $\operatorname{rps} B$ & 3340672 & $\begin{array}{l}30 \text { ribosomal } \\
\text { protein S2 }\end{array}$ & YP_221868.1 & Q57CX7 & 256 & BruAb1_1168 & 259 & 29308 & 27999 & 5.88 & 29 & ribosome & $\begin{array}{l}\text { J: Translation, } \\
\text { ribosomal } \\
\text { structure and } \\
\text { biogenesis }\end{array}$ \\
\hline 204 & ubiG & 3340925 & $\begin{array}{l}\text { 3-demethylubiquinone- } \\
9 \text { 3-methyltransferase }\end{array}$ & YP_415219.1 & Q2YLN5 & 248 & BAB1_1875 & 410 & 27653 & 27486 & 5.79 & 31 & cytoplasm & $\begin{array}{l}\text { E: Amino acid } \\
\text { transport and } \\
\text { metabolism }\end{array}$ \\
\hline 207 & dapB & 3341712 & $\begin{array}{l}\text { dihydrodipicolinate } \\
\text { reductase }\end{array}$ & YP_223731.1 & Q576R4 & 268 & BruAb2_0991 & 536 & 28792 & 27605 & 5.92 & 45 & cytoplasm & $\begin{array}{l}\text { E: Amino acid } \\
\text { transport and } \\
\text { metabolism }\end{array}$ \\
\hline
\end{tabular}


Table 3 Identification of matched immunoreactive proteins of $B$. abortus that reacted with $B$. abortus-positive bovine antisera (Continued)

\begin{tabular}{|c|c|c|c|c|c|c|c|c|c|c|c|c|c|c|}
\hline 218 & BruAb2_0647 & 3342272 & $\begin{array}{l}\text { hypothetical protein } \\
\text { BruAb2_0647 }\end{array}$ & YP_223419.1 & Q577X6 & 224 & BruAb2_0647 & 302 & 24961 & 24805 & 4.83 & 34 & unknown & $\begin{array}{l}\text { Q: Secondary } \\
\text { metabolites } \\
\text { biosynthesis, } \\
\text { transport, and } \\
\text { catabolism }\end{array}$ \\
\hline 227 & BruAb2_0628 & 3342294 & $\begin{array}{l}\text { metal-dependent } \\
\text { hydrolase }\end{array}$ & YP_223400.1 & Q577Z5 & 237 & BruAb2_0628 & 511 & 25223 & 25124 & 5.58 & 51 & cytoplasm & $\begin{array}{l}\text { R: General } \\
\text { function } \\
\text { prediction only }\end{array}$ \\
\hline 228 & msrA & 3341844 & $\begin{array}{l}\text { methionine sulfoxide } \\
\text { reductase A }\end{array}$ & YP_223747.1 & Q576P8 & 218 & BruAb2_1009 & 167 & 24230 & 24017 & 5.65 & 20 & cytoplasm & $\begin{array}{l}\text { O: } \\
\text { Posttranslational } \\
\text { modification, } \\
\text { protein turnover, } \\
\text { chaperones }\end{array}$ \\
\hline 231 & BruAb1_1470 & 3340810 & $\begin{array}{l}50 S \text { ribosomal } \\
\text { protein } \mathrm{L} 25\end{array}$ & YP_222213.1 & Q57BY2 & 207 & BruAb1_1470 & 171 & 22369 & 22383 & 5.91 & 47 & ribosome & $\begin{array}{l}\text { J: Translation, } \\
\text { ribosomal } \\
\text { structure and } \\
\text { biogenesis }\end{array}$ \\
\hline 239 & BruAb1_0588 & 3339410 & $\begin{array}{l}\text { Fe-Mn superoxide } \\
\text { dismutase }\end{array}$ & YP_221327.1 & Q57EG8 & 199 & BruAb1_0588 & 359 & 22526 & 22540 & 5.83 & 37 & unknown & $\begin{array}{l}\text { P: Inorganic ion } \\
\text { transport and } \\
\text { metabolism }\end{array}$ \\
\hline 240 & rocF & 3341875 & arginase & YP_223125.1 & POA2Y1 & 306 & BruAb2_0333 & 188 & 33415 & 33182 & 5.63 & 24 & unknown & $\begin{array}{l}\text { P: Inorganic ion } \\
\text { transport and } \\
\text { metabolism }\end{array}$ \\
\hline 243 & gpm & 3341713 & phosphoglyceromutase & YP_223732.1 & Q576R3 & 206 & BruAb2_0992 & 446 & 22929 & 22886 & 6.16 & 43 & cytoplasm & $\begin{array}{l}\text { G: Carbohydrate } \\
\text { transport and } \\
\text { metabolism }\end{array}$ \\
\hline 253 & $\sec B$ & 3339678 & $\begin{array}{l}\text { preprotein translocase } \\
\text { subunit SecB }\end{array}$ & YP_222709.1 & POC125 & 163 & BruAb1_2047 & 343 & 17924 & 17878 & 4.89 & 46 & cytoplasm & $\begin{array}{l}\text { O: } \\
\text { Posttranslational } \\
\text { modification, } \\
\text { protein turnover, } \\
\text { chaperones }\end{array}$ \\
\hline 254 & ndk & 3339959 & $\begin{array}{l}\text { nucleoside } \\
\text { diphosphate kinase }\end{array}$ & YP_221449.1 & Q57E46 & 140 & BruAb1_0713 & 58 & 15269 & 15278 & 5.27 & 20 & cytoplasm & $\begin{array}{l}\text { F: Nucleotide } \\
\text { transport and } \\
\text { metabolism }\end{array}$ \\
\hline 257 & BruAb2_0845 & 3341366 & $\begin{array}{l}\text { hypothetical protein } \\
\text { BruAb2_0845 }\end{array}$ & YP_223598.1 & Q577E7 & 177 & BruAb2_0845 & 500 & 18506 & 18517 & 5.02 & 43 & unknown & $\begin{array}{l}\text { S: Function } \\
\text { unknown }\end{array}$ \\
\hline 263 & ohr & 3341640 & $\begin{array}{l}\text { organic hydroperoxide } \\
\text { resistance protein }\end{array}$ & YP_223139.1 & Q579A6 & 140 & BruAb2_0347 & 8 & 14337 & 14232 & 5.63 & 13 & unknown & $\begin{array}{l}\text { R: General } \\
\text { function } \\
\text { prediction only }\end{array}$ \\
\hline
\end{tabular}

${ }^{\mathrm{a}}$ Gene ID, protein ID, accession no. and locus tag were retrieved from the NCBInr database.

${ }^{\mathrm{b}}$ Theoretical molecular weight from the UniProtKB database entry.

'Subcellular locations were predicted using PSORTb v. 2.0.4.

dCluster of orthologous groups (COG) protein database generated by comparing microbial genomes from the NCBI COG. 
chaperones, including DnaK, GroEL and the HtrA protease, are known as stress proteins and virulence factors $[25,30,31]$; in our study, at least one chaperone protein, the pre-protein translocase subunit ( $\mathrm{SecB}$ ) was specific to a certain B. abortus-infection stage. SecB is a molecular chaperone specific to the proteobacteria, which comprises most gram-negative bacteria that are medically and industrially relevant [32]. SecB is required for the normal export of pre-proteins out of the cytoplasm, keeping them in a translocation-competent state.

Prevention of Brucella infections in livestock generally involves the use of live attenuated vaccines such as $B$. abortus (RB51 or S19) [33,34] and B. melitensis Rev1 [35]. S19 and Rev1 had the major disadvantage of inducing O-side chain-specific antibodies, which causes crossreactivity during diagnosis; with RB51, the recovery of virulence was a major problem [36]. Consistently, several studies have focused on developing next-generation vaccines that are more safe and effective. Therefore, the immunogenic Brucella proteins identified in this study might provide supporting information for developing valid vaccine candidates that can elicit an efficient and specific immune response. Furthermore, it is important to consider the diagnostic method used depending on the animal and the stage of infection. Modern diagnostic methods are based on molecular approaches developed by proteomic analyses, and these advanced tools might soon replace the older, limited diagnostic methods. We suggest that the candidate proteins elucidated in this study might contribute a valuable solution to the present problems in the diagnosis of brucellosis, independent of the stage of infection. Ultimately, our investigation could provide helpful insight to advance the potential of immunogenic proteins as determinants for serological diagnosis and as novel tools for prevention of Brucella infection.

\section{Competing interests}

The authors declared that they have no competing interests.

\section{Authors' contributions}

LJ carried out all experiments, contributed to data collection and analysis, and participated in drafting the manuscript; HLS and AWBR participated in the design of the study and contributed to the antigen preparation; DGK and $\mathrm{HTH}$ contributed to immunoblotting and participated in the design of the study; WM participated in the design of the study; $\mathrm{MH}, \mathrm{SCJ}$ and HSY participated in the preparation of cattle infection; KS participated in the design of the study, carried out the data analysis, conceived the experiment and prepared the manuscript. All authors read and approved the final manuscript.

\section{Acknowledgements}

The work was supported by iPET (112012-3); Ministry of Agriculture, Food and Rural Affairs, and Animal and Plant Quarantine Agency, Korea.

\section{Author details}

${ }^{1}$ Animal and Plant Quarantine Agency, Anyang, Gyeonggi-do 430-757, Republic of Korea. Institute of Animal Medicine, College of Veterinary Medicine, Gyeongsang National University, Jinju, 660-701, Republic of Korea. ${ }^{3}$ Department of Infectious Diseases, College of Veterinary Medicine, Seoul National University,
Seoul 151-742, Republic of Korea. ${ }^{4}$ Institute of Agriculture and Life Science, Gyeongsang National University, Jinju, 660-701, Republic of Korea.

Received: 1 May 2014 Accepted: 13 January 2015

Published online: 01 March 2015

References

1. Seleem MN, Boyle SM, Sriranganathan N (2010) Brucellosis: a re-emerging zoonosis. Vet Microbiol 140:392-398

2. Al Dahouk S, Nockler K (2011) Implications of laboratory diagnosis on brucellosis therapy. Expert Rev Anti Infect Ther 9:833-845

3. McGiven JA (2013) New developments in the immunodiagnosis of brucellosis in livestock and wildlife. Rev Sci Tech 32:163-176

4. Nielsen K, Yu WL (2010) Serological diagnosis of brucellosis. Prilozi 31:65-89

5. McGiven JA, Stack JA, Perrett LL, Tucker JD, Brew SD, Stubberfield E, MacMillan AP (2006) Harmonisation of European tests for serological diagnosis of Brucella infection in bovines. Rev Sci Tech 25:1039-1053

6. Gall D, Nielsen K, Nicola A, Renteria T (2008) A proficiency testing method for detecting antibodies against Brucella abortus in quantitative and qualitative serological tests. Rev Sci Tech 27:819-828

7. Nielsen K, Smith P, Widdison J, Gall D, Kelly L, Kelly W, Nicoletti P (2004) Serological relationship between cattle exposed to Brucella abortus, Yersinia enterocolitica O:9 and Escherichia coli O157:H7. Vet Microbiol 100:25-30

8. Laurent TC, Mertens P, Dierick JF, Letesson JJ, Lambert C, De Bolle X (2004) Functional, molecular and structural characterisation of five anti-Brucella LPS mAb. Mol Immunol 40:1237-1247

9. Yang $Y$, Wang L, Yin J, Wang $X$, Cheng S, Lang X, Wang X, Qu H, Sun C, Wang J, Zhang R (2011) Immunoproteomic analysis of Brucella melitensis and identification of a new immunogenic candidate protein for the development of brucellosis subunit vaccine. Mol Immunol 49:175-184

10. Connolly JP, Comerci D, Alefantis TG, Walz A, Quan M, Chafin R, Grewal P, Mujer CV, Ugalde RA, DelVecchio VG (2006) Proteomic analysis of Brucella abortus cell envelope and identification of immunogenic candidate proteins for vaccine development. Proteomics 6:3767-3780

11. Ko KY, Kim JW, Her M, Kang SI, Jung SC, Cho DH, Kim JY (2012) Immunogenic proteins of Brucella abortus to minimize cross reactions in brucellosis diagnosis. Vet Microbiol 156:374-380

12. Bradford MM (1976) A rapid and sensitive method for the quantitation of microgram quantities of protein utilizing the principle of protein-dye binding. Anal Biochem 72:248-254

13. Gorg A, Weiss W, Dunn MJ (2004) Current two-dimensional electrophoresis technology for proteomics. Proteomics 4:3665-3685

14. Silva E, O'Gorman M, Becker S, Auer G, Eklund A, Grunewald J, Wheelock AM (2010) In the eye of the beholder: does the master see the SameSpots as the novice? J Proteome Res 9:1522-1532

15. Perkins DN, Pappin DJ, Creasy DM, Cottrell JS (1999) Probability-based protein identification by searching sequence databases using mass spectrometry data. Electrophoresis 20:3551-3567

16. The EXPASY Database [http://www.expasy.org/proteomics].

17. Gardy JL, Laird MR, Chen F, Rey S, Walsh CJ, Ester M, Brinkman FS (2005) PSORTb v. 2.0: expanded prediction of bacterial protein subcellular localization and insights gained from comparative proteome analysis. Bioinformatics 21:617-623

18. Makarova KS, Sorokin AV, Novichkov PS, Wolf YI, Koonin EV (2007) Clusters of orthologous genes for 41 archaeal genomes and implications for evolutionary genomics of archaea. Biol Direct 2:33

19. Pappas $G$ (2010) The changing Brucella ecology: novel reservoirs, new threats. Int J Antimicrob Agents 36(Suppl 1):S8-11

20. Vrioni G, Pappas G, Priavali E, Gartzonika C, Levidiotou S (2008) An eternal microbe: Brucella DNA load persists for years after clinical cure. Clin Infect Dis 46:e131-136

21. Christopher S, Umapathy BL, Ravikumar KL (2010) Brucellosis: review on the recent trends in pathogenicity and laboratory diagnosis. J Lab Physicians 2:55-60

22. McGiven JA, Sawyer J, Perrett LL, Brew SD, Commander NJ, Fisher A, McLarnon S, Harper K, Stack JA (2008) A new homogeneous assay for high throughput serological diagnosis of brucellosis in ruminants. J Immunol Methods 337:7-15

23. Doytchinova IA, Flower DR (2007) Identifying candidate subunit vaccines using an alignment-independent method based on principal amino acid properties. Vaccine 25:856-866 
24. Norris MH, Kang Y, Lu D, Wilcox BA, Hoang TT (2009) Glyphosate resistance as a novel select-agent-compliant, non-antibiotic-selectable marker in chromosomal mutagenesis of the essential genes asd and dapB of Burkholderia pseudomallei. Appl Environ Microbiol 75:6062-6075

25. Teixeira-Gomes AP, Cloeckaert A, Zygmunt MS (2000) Characterization of heat, oxidative, and acid stress responses in Brucella melitensis. Infect Immun 68:2954-2961

26. Wagner MA, Eschenbrenner M, Horn TA, Kraycer JA, Mujer CV, Hagius S, Elzer P, DelVecchio VG (2002) Global analysis of the Brucella melitensis proteome: Identification of proteins expressed in laboratory-grown culture. Proteomics 2:1047-1060

27. Byrgazov K, Manoharadas S, Kaberdina AC, Vesper O, Moll I (2012) Direct interaction of the $\mathrm{N}$-terminal domain of ribosomal protein $\mathrm{S} 1$ with protein S2 in Escherichia coli. PLoS One 7:e32702

28. Barbier T, Nicolas C, Letesson JJ (2011) Brucella adaptation and survival at the crossroad of metabolism and virulence. FEBS Lett 585:2929-2934

29. Hantke K (2001) Iron and metal regulation in bacteria. Curr Opin Microbiol 4:172-177

30. Ghasemi A, Salari MH, Zarnani AH, Pourmand MR, Ahmadi H, Mirshafiey A Jeddi-Tehrani M (2013) Immune reactivity of Brucella melitensis-vaccinated rabbit serum with recombinant Omp31 and DnaK proteins. Iran J Microbiol 5:19-23

31. Abbady AQ, Al-Daoude A, Al-Mariri A, Zarkawi M, Muyldermans S (2012) Chaperonin GroEL a Brucella immunodominant antigen identified using Nanobody and MALDI-TOF-MS technologies. Vet Immunol Immunopathol 146:254-263

32. Driessen AJ (2001) SecB, a molecular chaperone with two faces. Trends Microbiol 9:193-196

33. Moriyon I, Grillo MJ, Monreal D, Gonzalez D, Marin C, Lopez-Goni I, MainarJaime RC, Moreno E, Blasco JM (2004) Rough vaccines in animal brucellosis: structural and genetic basis and present status. Vet Res 35:1-38

34. Thomas EL, Bracewell CD, Corbel MJ (1981) Characterisation of Brucella abortus strain 19 cultures isolated from vaccinated cattle. Vet Rec 108:90-93

35. Banai M (2002) Control of small ruminant brucellosis by use of Brucella melitensis Rev.1 vaccine: laboratory aspects and field observations. Vet Microbiol 90:497-519

36. Durward MA, Harms J, Magnani DM, Eskra L, Splitter GA (2010) Discordant Brucella melitensis antigens yield cognate CD8+ T cells in vivo. Infect Immun 78:168-176

\section{Submit your next manuscript to BioMed Central and take full advantage of:}

- Convenient online submission

- Thorough peer review

- No space constraints or color figure charges

- Immediate publication on acceptance

- Inclusion in PubMed, CAS, Scopus and Google Scholar

- Research which is freely available for redistribution 